\title{
TANTANGAN DEMOKRASI DALAM PILKADA DITENGAH \\ KEBIJAKAN PANDEMI PEMERINTAH
}

\author{
Alya Tata Riani \\ Institut Ilmu Kesehatan STRADA Indonesia \\ alyatata456@gmail.com
}

\begin{abstract}
ABSTRAK
Pemilihan Kepala Daerah Tahun ini menjadi pemilihan yang berbeda dari sebelumya. Pemilihan serentak kali ini dilaksanakan di tengah pandemi corona virus disease 2019 (Covid-19). Hal ini tentu akan menjadi tantangan tersendiri bagi para pengawas pemilihan dalam menjalankan tugas dan fungsinya. Mulai dari persiapan sampai dengan pelaksanaan pengawasannya demi terwujudnya nilai-nilai demokrasi dalam pemilihan. Sehingga pengawasan Bawaslu akan menjadi menarik untuk dikaji. Pengawasan yang dilaksanakan oleh Bawaslu pada Pilkada era pandemi covid-19 menjadi fokus dalam penelitian dengan menggunakan teori demokrasi, Sehingga dalam penelitian pelaksanaan demokrasi di era Pandemi Covid-19 dalam studi pegawasan menunjukkan bahwa pelaksanaan pemilihan di Kabupaten secara teknis pengawasannya tidak berubah. Namun terdapat tambahan tugas pengawasan Bawaslu Kabupaten yaitu selain mengawasi prosedur, mekanisme dan tata cara pelaksanan pilkada, Bawaslu Kabupaten juga harus mengawasi penerapan protokol kesehatan untuk menjamin pelaksanaan pilkada di Kabupaten tidak menimbulkan klaster baru di penyelenggara, peserta maupun pemilih, serta upaya memutus mata rantai penyebaran Covid-19. Adanya pilkada era pandemi Covid-19 ini berimplikasi pada pelaksanaan pengawasan Bawaslu Kabupaten, mulai dari bertambahnya tugas pengawasan Bawaslu Kabupaten, adanya optimalisasi anggaran yang berefek pada penguatan SDM sampai dengan proses pelaksanaan pengawasan dan pilkada yang harus menggunakan protokol kesehatan.
\end{abstract}

Kata Kunci : Demokrasi, Pilkada, Pandemi, Covid-19. 


\section{Latar Belakang}

Indonesia merupakan negara demokrasi yang dipimpin oleh seorang presiden sebagaimana sudah dijelaskan dalam Undang-Undang Dasar 1945. Tercatat bahwa pemilihan langsung yang ada di Indonesia sudah dimulai dari tahun 1955. Pelaksanaan pemilihan di Negara Indonesia menggunakan sistem pemilihan langsung, dimana rakyat memiliki kedaulatan penuh dalam menentukan calon pemimpinnya. Pemilihan di Indonesia digelar pada setiap satu periode sekali atau lima tahunan yang dilaksanakan oleh penyelenggara Pemilu yaitu Komisi Pemilihan Umum (KPU) sebagai pelaksana teknis, Badan Pengawas Pemilihan Umum (Bawaslu) sebagai Lembaga Pengawas Pemilu dan Dewan Kehormatan Penyelenggara Pemilu (DKPP) sebagai Lembaga yang menangani kode etik penyelenggara pemilu.

Ketiga Lembaga tersebut merupakan lembaga Negara yang bersifat
Independen sebagaimana diatur dalam Undang-Undang 7 tahun 2017 tentang Pemilihan Umum. Sesuai amanat amandemen Undang-Undang Dasar Negara Republik Indonesia tahun 1945, kedaulatan berada di tangan rakyat dan dilaksanakan menurut Undang-Undang. Pemilu merupakan pemilihan langsung untuk menentukan pemimpin ditingkat nasional, Provinsi ataupun Kabupaten/Kota serta menentukan wakil rakyat yang akan duduk di Parlemen dengan melibatkan masyarakat sebagai pemilik kedaulatan atas negara. Sehingga penyelenggaraan Pemilihan Umum wajib memberikan jaminan suara rakyat dapat diberikan secara langsung, umum, bebas, rahasia, jujur dan adil sesuai amanat UndangUndang Nomor 7 Tahun 2017 Pasal 2.

Pemilihan serantak tahun 2020 berbeda dengan pemilihan sebelumnya, perbedaannya pada posisi adanya bencana non alam yang menimpa Indonesia atau bahkan seluruh dunia. Bencana non alam ini 
merupakan adanya corona virus disease 2019 (Covid-19). Kementerian Kesehatan menyatakan bahwa Covid-19 adalah salah satu keluarga besar virus yang dapat menyebabkan manusia dan hewan menjadi sakit. Virus ini pada manusia dapat menyebabkan infeksi pada saluran pernapasan, biasanya dimulai dengan sakit flu biasa sampai dengan penyakit yang serius seperti Middle East Respiratory Syndrome (MERS) dan Sindrom Pernafasan Akut Berat/ Severe Acute Respiratory Syndrome (SARS). Virus Corona ditemukan pada manusia yang dimulai dengan adanya kejadian di Wuhan Cina, padami Desember 2019 yang kemudian dinamai dengan Severe Acute Respiratory Syndrome Coronavirus 2 (SARS-COV2) dan dapat menyebabkan penyakit

COVID-19. Adanya virus yang menyebar ini membuat pemerintah terfokus dalam menanggulangi atau mencegah penyebarannya, mulai dari restrukturisasi anggaran sampai dengan pelaksanaan programprogram pemerintah yang berbasis pencegahan Covid-19. Selain itu, adanya Covid ini juga membuat pemerintah untuk terus bersosialisasi dan mempersuasi masyarakat supaya bersama-sama mencegah Virus tersebut.

\section{Khasus/Masalah}

sebagai Lembaga penyelenggara yang mengawasi jalannya pemilihan Bupati dan Wakil Bupati Kabupaten Tahun mempunyai tantangan tersendiri dengan adanya Bencana Nonalam Covid-19. Selain mengawasi jalannya pilkada, Bawaslu Kabupaten juga harus mencegah penyebaran Covid-19 mengingat bahwa Bawaslu Kabupaten bagian dari Lembaga Negara. Bagaimana pelaksanaan pilkada serentak era pandemi Covid19 di

Kabupaten, bagaimana pengawasan tahapan pilkada serentak era pandemi Covid19 di Kabupaten

\section{Tinjauan Pustaka}

Demokrasi Dalam Pilkada Serentak 2020 Era Pandemi Covid-19 memiliki 3 (tiga) kajian teori yang 
akan dipakai, yaitu Teori Demokrasi,Teori Pengawasan dan Teori Partai Politik Berikut ini merupakan pembahasan dari ketiga teori:

a. Teori Demokrasi

Demokrasi secara umum diartikan sebagai sebuah konsep pemerintahan oleh, dari dan untuk rakyat. Istilah demokrasi berasal dari bahasa Yunani, yakni demokratia. Kata ini terbentuk dari kata demos yang berarti rakyat, dan kratos yang berarti kekuatan atau kekuasaan. Jadi, demokrasi bisa diartikan sebagai kekuasaan rakyat. Pada negara yang menganut sistem demokrasi, rakyat ikut berperan serta dalam pemerintahan untuk pengurusan kehidupan bersama dalam negara.

Setiap warga Negara di dunia tentunya mendambakan suatu pemerintahan yang demokratis. Sehingga pemerintahan yang demokratis dapat memberikan kesempatan kepada masyarakat untuk berpartisipasi secara maksimal dalam memberikan hak dan pendapatnya. Selain itu, dapat menghargai setiap pendapat atau prestasi masyarakat. sehingga demokrasi sangat penting untuk selalu dipelihara, dikembangkan dan. Hari ini demokrasi hanya dijadikan sebagai sistem politik oleh masyarakat dunia yang diyakini sebagai salah satu sistem terbaik dalam mencapai tujuan bernegara.

b. Teori Pengawasan

Pemilihan merupakan bentuk ekspresi formal masyarakat yang menggunakan hak pilihnya dan selanjutnya diakumulasikan apa akan ada pergantian kekuasaan/ pemerintahan ataukah tidak. Harrop dan Miller (1987:2) menjelaskan bahwa "Pemilu 
adalah sebuah preferensi ekspresi formal yang diatur untuk kemudian ditampung dan ditransformasikan kedalam sebuah keputusan kelompok tentang siapa yang akan memerintahapakah ada pergantian dalam kepemimpinan pemerintahan atau tidak".

Pengawasan adalah suatu bentuk proses untuk dapat menjamin bahwa kegiatan yang sedang berjalan sesuai dengan rencaana, hal ini dikemukakan oleh Stoner dan Freeman. (Kartini, 2017:156). Kemudian Koontz menyatakan pendapatnya bahwa pengawasan itu untuk melaksanakan pengukuran serta tindakan atas kinerja yang berfungsi untuk dapat merencanakan suatu cara dan meyakinkan organisasi secara objektif dalam mencapai suatu tujuan. (Kartini, 2017:156). Kemudian dalam Bahasa yang sederhana dijelaskan bahwa pengawasan merupakan suatu kegiatan yang direalisasikan supaya visi, misi atau tujuan organisasi tercapai dengan lancar tanpa ada penyimpangan, kegiatan untuk dapat mengetahui atau menilai kenyataan yang sebenarnya terkait dengan pelaskanaan tugas sudah sesuai dengan prosedur atau belum.

c. Teori Partai Politik

Teori dalam penelitian ini juga menggunakan teori Partai Politik. Menurut Miriam budiarjo Partai politik adalah organisasi politik yang menjadi sarana masyarakat untuk menyalurkan aspirasi. Partai politik menjadi alat bagi para kelompok sosial tertentu untuk memperjuangan

kepentingannya dan tentunya memiliki peran sentral dalam sebuah negara. Sehingga dalam negara demokrasi, adanya partai politik 
merupakan hal yang mutlak.

Menurut Carl J. Friedrich

mendefinisikannya "sebagai

sekolompok manusia yang

terorganisir secara stabil

dengan tujuan merebut atau

mempertahankan penguasaan

terhadap pemerintahan bagi

pimpinan partainya dan

berdasarkan penguasaan ini,

memberikan kepada anggota

partainya kemanfaatan yang

bersifat idiil dan materiil".

Kemudian Sigmund

Neumann mendefinisikannya sebagai "organisasi dari aktivis-aktivis politik yang berusaha untuk menguasai kekuasaan pemerintahan serta merebut dukungan rakyat melalui persaingan dengan suatu golongan arau golongangolongan lain yang mempunyai pandangan yang berbeda". Lebih lanjut Giovanni Sartori mendefinisikannya sebagai “suatu kelompok politik yang mengikuti pemilihan umum dan mampu menempatkan calon-calonnya untuk menduduki jabatan-jabatan public". (Budiardjo, 2009: 403-405)

\section{Pembahasan}

Pelaksanaan pilkada Tahun 2020 menjadi sejarah baru dalam pemilihan di Indonesia. Hal ini dikarenakan pelaksanaan pilkada serentak 2020 digelar di tengah pandemi Covid-19. Namun pelaksanaan pilkada Tahun 2020 tanpa mengurangi nilai-niai dan prinsip-prinsip demokrasi seperti penyelenggaran pilkada sebelumnya. Hanya saja dalam pelaksanaannya harus diiringi dengan penerapan protokol kesehatan. Sehingga secara umum pilkada 2020 tidak terjadi perubahan yang signifikan dalam artian masih sama seperti pemilihan sebelumnya. Indonesia merupakan salah satu negara yang melaksanakan pilkada serentak 2020 di era pendemi Covid-19.

Tahapan pelaksanaan pilkada sendiri pada dasarnya juga tidak jauh berbeda dengan tahapan pelaksanaan pemilihan sebelumnya. Namun yang 
membedakan adalah setiap tahapan yang berjalan harus di iringi dengan penerapan Protokol Kesehatan sebagai bentuk upaya pemutusan mata rantai penyebaran Covid-19. Hal ini sesuai yang diamanatkan oleh Undang-Undang Nomor 6 Tahun 2020 bahwa pilkada serentak 2020 dapat dilanjutkan dengan syarat semua pihak terkait harus mematuhi protokol kesehatan. Penerapan Protokol kesehatan tersebut diawali dengan perubahan regulasiregulasi pelaksanaan pemilihan, baik Peraturan KPU ataupun Peraturan Bawaslu. Seluruh peraturan yang dipakai dalam pelaksanaan pemilihan diisi dengan penerapan Protokol Kesehatan. Hal tersebut merupakan bentuk Komitmen Lembaga penyelenggara untuk ikut serta memutus mata rantai penyebaran Covid19 yang sempat menunda jalannya pelaksanaan pilkada. Pelaksanaan tahapan pemilihan juga sempat ditunda karena adanya wabah pandemi Covid-19 yang ditetapkan sebagai bencana Nasional Nonalam. Penundaan tersebut mulai bulan April sampai dengan Mei atau yang lebih tepatnya adalah setelah tahapan pelantikan Desa/Kelurahan. Penundaan tersebut tidak hanya terjadi di Indonesia melainkan juga seluruh negara yang melaksanakan pemilihan Kepala Daerah.

Secara umum pelaksanaan pilkada di tengah Pandemi Covid dilaksanakan sesuai dengan nilai-nilai demokrasi yang tercantum dalam UUD 1945. Pilkada ditengah pandemic memang terdapat kendala dalam teknis pelaksanaanya, selain itu, terdapat implikasi dalam pelaksanaan pilkada di tengah pandemic. Bawaslu Kabupaten juga merasakan adanya pandemi Covid-19 tersebut menjadikan beberapa kendala pengawasan dan berimplikasi terhadap pengawasan Bawalsu Kabupaten sendiri juga mendapatkan beban tambahan pengawasn yaitu pengawasan protocol kesehatan.

\section{Kesimpulan}

Pelaksanaan pemilihan Kepala Daerah di Kabupaten tahun 2020 merupakan pemilihan bersejarah. Hal ini disebabkan karena pelaksanaannya di era pandemi 
Covid-19. Adanya pandemi ini tentu membuat Bawaslu Kabupaten menjadi bertambah beban kinerjanya. Semula Bawaslu Kabupaten hanya fokus mengawasi prosedur, mekanisme dan tata cara pelaksanaan pemilihan pada setiap Tahapan. Namun adanya Pandemi Covid-19 ini membuat beban kerja pengawasan Bawaslu Kabupaten Tuban menjadi bertambah yaitu Pengawasan Penerapan Protokol Kesehatan.

Pelaksanaan pemilihan di tengah pandemic Covid-19 ini pada dasarnya tidak mengubah teknis pengawasan Bawaslu Kabupaten dan Teknis pelaksanaan pemilihan pada setiap tahapan. Namun, pada setiap pengawasan tahapan pemilihan, harus selalu di iringi dengan penearapan protocol Kesehatan. Hal ini di karenakan bentuk komitmen Bawaslu Kabupaten sebagai Lembaga Negara untuk memutus mata rantai penyebaran Covid-19. Apalagi pda pelaksanaan pemilihan ini, Bawaslu Kabupaten menjadi leading sector Kelompok Kerja Pencegahan Penyebaran Covid-19.

\section{Daftar Pustaka}

Riani, A. T. SOLIDARITAS MAHASISWA DALAM MEMPERKOKOH PERSATUAN DAN KESATUAN BANGSA INDONESIA.

Sodik, M. A., \& Nzilibili, S. M. M. (2017). The Role Of Health Promotion And Family Support With Attitude Of Couples Childbearing Age In Following Family Planning Program In Health. Journal of Global Research in Public Health, 2(2), 82-89.

Tule, A. R., Siyoto, S., Dwianggimawati, M. S., \& Sodik, M. A. (2018). The Analysis Factors Affecting Interest In Medication Of Receipt Help Aid Bpjs Participant In Balowerti 
Public Health Center Kediri City. Journal of Global Research in Public Health, 3(1), 6875.

Sarip, S., Syarifudin, A., \& Muaz, A. (2020). Dampak Covid-19 Terhadap Perekonomian Masyarakat Dan Pembangunan Desa. Al-Mustashfa: Jurnal Penelitian Hukum Ekonomi Syariah, 5(1), 10-20.

Hilman, Y. A., Khoirurrosyidin, K., \& Lestarini, N. (2020). Peta Politik Pemilukada Kabupaten Ponorogo 2020 di Tengah Pandemi Covid-19. Politicon: Jurnal Ilmu Politik, 2(2), 129-148. 